16 Thomson AM. Growth, heredity and nutrition. Eugenics Review 1959;51:157-62.

17 Baird D. Environment and reproduction. Br f Obstet Gynaecol 1980;87:1057-67.

18 Baird D. Changing problems and priorities in obstetrics. Br F Obstet Gynaecol 1985;82:115-21

19 Himsworth H. Epidemiology, genetics and sociology. F Biosoc Sci 1984;16:159-76.

21 Rush D, Cassano P. Relationship of cigarette smoking and social class to birth weight and perinata mortality among all births in Britain, 5-11 April 1970. I Epidemiol Community Health 1983;37:249-55

22 Sexton $M$, Hebel JR. A clinical trial of change in maternal smoking and its effect on birth weight. 7AMA 1984;251:911-5.

3 West RR, Lowe CR. Regional variations in need for and provision and use of child health services in England and Wales. BrMed $\mathcal{F}$ 1976;ii: 843-6.

24 Brotherston J. Inequality: is it inevitable? In: Carter $\mathrm{CO}$, Peel J, eds. Equalities and inequalities in Brotherston J. Inequality: is it inevitable? In: Car
health. London: Academic Press, 1976:73-104.

25 Downham MAPS, White EMcC, Moss TR. A study of childhood morbidity in relation to the provision of child health services in Newcastle-upon-Tyne, $1975 \& 1976$. Health Trend 1980;12:96-8

26 Taylor EM, Emery JL. Family and community factors associated with infant deaths that might be preventable. Br Med $\mathcal{J}$ 1983;287:871-4.

27 Hart JT. The inverse care law. Lancet 1971;i:405-12.

28 Gould SJ. The mismeasure of man. Harmondsworth: Pelican Books, 1984.

29 Thunhurst C. Social inequalities in health-the medical empire strikes back. Radical Community Medicine 1984:Sept:35-7.

30 Lindgren G. Height, weight and menarche in Swedish urban school children in relation to indgren G. Height, weight and menarche in Swedish urban schoc
economic and regional differences. Ann Hum Biol 1976;3:501-28.

31 Sjolin S. Infant mortality in Sweden. In: Wallace HM, ed. Health care of mothers and children in national health services. Cambridge, Mass: Ballinger, 1975:229-40

32 Erickson R, Aberg R. Valford i forandring: levnadsvillkor i Sverige 1968-81. Institutet for Social Forskning, 1984.

33 Fox AJ, Goldblatt PO, Jones DR. Social class mortality differentials: artefact, selection or life circumstances. F Epidemiol Community Health 1985;39:1-8.

\section{Thyroxine replacement treatment: clinical judgment or biochemical control?}

Hypothyroidism is well recognised to be associated with hyperlipidaemia and coronary artery atheroma, and the initiation of replacement treatment with thyroxine is known to be hazardous. Even gradual restoration of metabolic rate using doses as small as $25 \mu \mathrm{g}$ daily may result in exacerbation of angina or the development of myocardial ischaemia, infarction, and sudden death. ${ }^{1}$ Indeed, restoring normal thyroid hormone concentrations without causing these cardiovascular complications has been compared with steering a course between Scylla and Charybdis. About two fifths of patients presenting with the combination of hypothyroidism and symptomatic ischaemic heart disease cannot tolerate a full replacement dose of thyroxine, ${ }^{2}$ and it is doubtful if the addition of $\beta$ adrenoceptor antagonists or vasodilators is of great benefit. Thus, rather than persevere with medical treatment, there is a case for considering coronary artery surgery at an early stage so that full replacement treatment may be established with safety. In a small series from the Mayo Clinic the presence of untreated or partially treated hypothyroidism did not adversely affect the results of surgery. ${ }^{3}$

What is the correct dose of thyroxine? Based on the amounts necessary to restore thyroid stimulating hormone concentrations to normal in patients with primary hypothyroidism the average daily requirement is $150 \mu \mathrm{g}$ as a single dose. ${ }^{4}$ Pituitary thyroid stimulating hormone secretion is, however, determined by both serum T3 and T4 through intrapituitary conversion of $\mathrm{T} 4$ to $\mathrm{T} 3$, whereas other tissues depend predominantly on the serum $\mathrm{T} 3$ concentration for intracellular T3. ${ }^{5}$ This raises the possibility that, unlike spontaneously developing hyperthyroidism when serum T3 concentrations are consistently raised, an absent thyroid stimulating hormone response to thyrotrophin releasing hormone may not necessarily imply overtreatment in patients receiving thyroxine when serum $\mathrm{T} 4$ concentrations may be raised in the presence of normal serum T3. Is there any harm in prescribing doses of thyroxine greater than those necessary to suppress secretion of thyroid stimulating hormone? In the past it was common practice to use $300 \mu \mathrm{g}$ or even $400 \mu \mathrm{g}$ thyroxine daily for hypothyroidism, goitre, or thyroid cancer without apparently producing clinical evidence of hyperthyroidism in most patients. Possibly the 5'-deiodinase systems responsible for peripheral conversion of $\mathrm{T} 4$ to $\mathrm{T} 3 \mathrm{are}$ less efficient at raised concentrations of serum $\mathrm{T} 4$, thus tending to maintain normal concentrations of serum T3. ${ }^{6}$ Such a mechanism must be only partially effective, however, otherwise thyrotoxicosis factitia would not exist. (These arguments about the relative safety of supraphysiological doses of thyroxine were relied on by the plaintiff in a recent prolonged libel action to dismiss the importance of raised serum T4 concentrations in patients to whom he had given, among other drugs and a diet, thyroid extract in a dose of $250 \mathrm{mg}$ daily for obesity. ${ }^{7}$ Thyroid extract, however, contains both thyroxine and triiodothyronine and, if taken in sufficient dosage to induce a high concentration of serum T4, it is almost invariably associated with a persistently raised serum T3 concentration and clinical evidence of hyperthyroidism. ${ }^{8}$ )

A more likely explanation for the difference between the dose of thyroxine required to suppress thyroid stimulating hormone and that necessary to produce clinical thyrotoxicosis is that clinical judgment is a crude index of thyroid function. Hyperthyroidism, like hypothyroidism, ${ }^{9}$ is almost certainly a graded disorder, with the patient with obvious severe thyrotoxicosis at one end and at the other the patient considered to have what is unsatisfactorily termed subclinical hyperthyroidism on the basis of abnormal biochemical results in the absence of clinical signs. Minor changes in serum T4 may, however, influence heart rate, urinary sodium excretion, and myocardial contractility. ${ }^{1011}$ Indeed, glutathione S-transferase activities are now known to be raised in patients in whom thyroxine replacement treatment has been associated with raised serum T4, but normal T3, indicating minor hepatocellular damage. ${ }^{12}$ None of these tissue effects will be evident clinically.

The cardiac complications of overt hyperthyroidism such as atrial fibrillation, cardiomyopathy, angina, focal myocarditis, ${ }^{13}$ and sudden death from presumed ventricular fibrillation ${ }^{14}$ are well recognised. What is not known is whether the higher so called replacement doses of thyroxine, which are in excess of those required to suppress secretion of thyroid stimulating hormone, may be important in the pathogenesis of these complications in the absence of overt thyrotoxicosis. Heart disease is common in the middle aged and elderly, and a causal relationship is unlikely to be considered when a patient on thyroxine $300 \mu \mathrm{g}$ daily develops angina or goes into ventricular fibrillation, particularly as the mortality rate is low even in overt hyperthyroidism.

As a council of wisdom rather than of perfection enough thyroxine should be given to maintain a normal concentration of serum free $\mathrm{T} 3,{ }^{15}$ preferably with a detectable but normal serum thyroid stimulating hormone concentration measured by a specific and sensitive immunoradiometric assay, and not to rely on reducing the dose only when serum T4 concentrations are high and associated with clinical features of hyperthyroidism. Current tests of thyroid function are so reliable that if there is a discrepancy between biochemical findings and clinical assessment the results of the tests, if confirmed, should usually determine the appropriate dose of replacement thyroxine.

ANTHONY D ToFT

Senior Lecturer and Honorary Consultant Physician

Royal Infirmary,

Edinburgh EH3 9YW 
1 Keating FR, Parkin TW, Selby JB, Dickinson LS. Treatment of heart disease associated with myxoedema. Prog Cardiovasc Dis 1961;3:364-81

2 Levine HD. Compromise therapy in the patient with angina pectoris and hypothyroidism. Am 7 Med 1980;69:411-8.

3 Hay ID, Duick DS, Vlietstra RE, Maloney JD, Pluth JR. Thyroxine therapy in hypothyroid patients undergoing coronary revascularisation: a retrospective analysis. Ann Intern Med 1981;95:456-7.

4 Evered D, Young ET, Ormston BJ, Menzies R, Smith PA, Hall R. Treatment of hypothyroidism: a reappraisal of thyroxine therapy. BrMed F 1973;iii:131-4

5 Larsen PR, Silva JE, Kaplan MM. Relationship between circulating and intracellular thyroid hormones: physiological and clinical implications. Endocr Rev 1981;2:87-102.

6 Nicoloff JT, Lum SMC, Spencer CA, Morris R. Peripheral autoregulation of thyroxine to triiodothyronine conversion in man. Horm Metab Res (Suppl) 1984;14:74-9.

7 Dyer C. Dr Gee defends his treatment. Br Med f 1984;289:1683-4.

8 Jackson IMD, Cobb WE. Why does anyone still use desiccated thyroid USP? Am $\mathcal{J}$ Med \begin{tabular}{l}
$1978 ; 64: 284-8$. \\
\hline
\end{tabular}

9 Evered DC, Ormston BJ, Smith PA, Hall R, Bird T. Grades of hypothyroidism. Br Med $\mathcal{F}$ 1973;i:657-62.

10 Bell GM, Sawers JSA, Forfar JC, Doig A, Toft AD. The effect of minor increments in plasma thyroxine on heart rate and urinary sodium excretion. Clin Endocrinol (Oxf) 1983;18:511-6.

11 Jennings PE, O'Malley BP, Griffin KE, Northover B, Rosenthal FD. Relevance of increased serum thyroxine concentrations associated with normal serum triiodothyronine values in hypothyroid patients receiving thyroxine: a case for "tissue thyrotoxicosis." $\mathrm{Br}$ Med $\mathcal{J}$ 1984;289:1645-7.

12 Beckett GJ, Kellett HA, Gow SM, Hussay AJ, Hayes JD, Toft AD. Elevated plasma glutathione $\mathrm{S}$-transferase concentrations in hyperthyroidism and in hypothyroid patients receiving $\mathrm{S}$-transferase concentrations in hyperthyroidism and in hypothyroid
thyroxine replacement: evidence for hepatic damage. $\mathrm{Br}$ Med $\mathrm{f}$ (in press).

13 Weller CV, Wanstrom RC, Gordon H, Bugher JC. Cardiac histopathology in thyroid disease. Am Heart $\mathcal{X}$ 1932;9:8-12.

14 Parker JLW, Lawson DH. Death from thyrotoxicosis. Lancet 1973;ii:894-5.

15 Pearce CJ, Himsworth RL. Total and free thyroid hormone concentrations in patients receiving maintenance replacement treatment with thyroxine. Br Med f 1984;288:693-5.

\section{Blood transfusion and surgery}

Concern about the acquired immune deficiency syndrome (AIDS) has resulted in major changes in blood transfusion practice in the United States and its impact is now making itself felt in Britain. Although the risk of acquiring AIDS by blood transfusion seems to be remote, and certainly less than that of developing hepatitis, it has provoked a timely reappraisal of attitudes to transfusion. Recent advances in laboratory techniques have reduced the time taken to perform a safe cross match to 30 to 40 minutes. Thus provided the patient has been grouped and screened for antibodies any surgical procedure that seldom causes loss of more than $20 \%$ of the total blood volume should no longer routinely be covered by two or three units of cross matched blood.

Ten years ago Sykes recommended that losses of this order should be replaced with non-sanguineous fluids. ' But this has not happened, chiefly because cross matched blood has usually been readily available. Nevertheless, cross matching of blood does nothing to reduce the incidence of the four or more serious diseases transmitted by viruses, nor of anaphylactic and delayed haemolytic reactions. ${ }^{2}$ The development of crystalline haemoglobin solutions and perfluorocarbons has not yet got to the stage where either of them has advantages over plasma or plasma substitutes.

Studies from different countries of the ratio of blood cross matched to blood transfused during routine operations show that practice is remarkably similar for procedures for which two or three units of blood are cross matched but seldom used..$^{3 \cdot 6}$ Seshadri and his colleagues have instituted a maximum order for blood for all routine elective operations, and this is adhered to unless the patient has antibodies or there are other unusual circumstances. ${ }^{5}$ Arguably it is time for British hospitals, which at present have a service based on arbitrary request, to adopt a similar approach.

There has never been any justification for transfusing a patient before elective surgery simply on the grounds that it might be expedient, and now patient resistance will probably, and rightly, put a stop to it. The accepted lower limit of haemoglobin of $10 \mathrm{~g} / \mathrm{dl}$ should not be abandoned: it represents a loss of about $25 \%$ of the oxygen carrying capacity of the blood and no anaesthetist can guarantee not to let his or her patient's cardiac output fall during the operation. Concentrations below $10 \mathrm{~g} / \mathrm{dl}$ are accompanied by a progressive increase in the bleeding time, ${ }^{7}$ and below $9 \mathrm{~g} / \mathrm{dl}$ the compensatory increase in dissociation of oxyhaemoglobin will no longer prevent a decrease in cardiac output. ${ }^{8}$

Demand for designated blood, either from relatives or by one of the methods making use of autologous blood, ${ }^{9}$ is increasing. Its application is necessarily restricted but it may prove useful in paediatric surgery and for operations that have a relatively predictable blood loss. Blood taken from relatives and by the so called predeposit autologous method (by which blood is taken from the patient days or even weeks preoperatively) is not popular with transfusion staff, who are understandably reluctant to see a two tier system develop. ${ }^{10}$ Yet, if clinicians become responsible for taking, storing, and administering such blood the present high standards of the transfusion service seem unlikely to be maintained. This problem may be overcome if autologous blood-obtained either by salvage autotransfusion or by deliberate haemodilution-is used. In salvage autotransfusion blood lost during surgery is collected and reinfused and this method deserves wider application than it has so far achieved. Deliberate haemodilution entails bleeding patients at the induction of anaesthesia and maintaining normovolaemia by infusion of clear fluids. This method is particularly suitable for patients whose haemoglobin concentrations are above the normal range, for high concentrations, in contrast to low ones, are known to be associated with increased surgical morbidity and mortality. ${ }^{1.15}$ The patient is bled until the packed cell volume reaches a predetermined level, usually $35 \%$, and the blood is anticoagulated and then reinfused to cover subsequent operative loss. ${ }^{16}$

In the United States active transfusion committees are a requirement of the Joint Commission on Accreditation of Hospitals. ${ }^{17}$ In the current ferment of public and professional concern about blood transfusion, hospitals in Britain would do well to follow this practice. If they drag their feet this may prove to be an aspect of clinical practice that will be called to account by their new managers.

P J HORSEY

Consultant Anaesthetist,

Southampton General Hospital,

Southampton SO9 4XY

1 Sykes MK. Indications for blood transfusion. Can Anaesth Soc $\mathcal{f}$ 1975;22:3-11.

2 Pineda AA, Taswell HF, Brzica SM. Delaved hemolytic transfusion reaction; an immunologic hazard of blood transfusion. Transfusion 1978;18:1-7.

3 Devitt JE. Blood wastage and cholecystectomy: a spin off from a peer review. Can Med Assoc 1973;109:120-1.

4 Rouault C, Greunhagen J. Reorganisation of blood ordering practices. Transfusion 1978;18: $448-53$.

5 Seshadri RS, Odell WR, Roxby D, Morley AA. Effective use of blood in elective surgical procedures. Med J Aust 1979;ii:575-8.

6 Dodds AJ, Pun A, Isbister JP, et al. A rational approach to crossmatching blood for elective surgery. Anaesth Intensive Care 1983;11:16-9.

7 Anonymous. The bleeding time and the haematocrit [Editorial]. Lancet 1984;i:997-8.

8 Gillies IDS. Anaemia and anaesthesia. Br f Anaesth 1974;46:589-602.

9 Horsey PJ. Blood transfusion. In: Atkinson RS, Hewer CLA, eds. Recent advances in anaesthesia and analgesia 14. London: Churchill Livingstone, 1982:89-103.

10 Bove JR. Transfusion associated AIDS-a cause for concern. N Engl f Med 1984;310:115-6.

11 Elwood PC. Anaemia. Lancet 1974;ii:1364-5.

12 Bouhoutsos J, Morris T, Chevatzas D, Martin P. The influence of haemoglobin and platelet levels on the results of arterial surgery. BrF Surg 1974;61:984-6.

13 Baily MJ, Johnston CLW, Yates CJP, Somerville PG, Dormandy JA. Preoperative haemoglobi as a predictor of outcome in diabetic amputations. Lancet 1979;ii:168-70.

14 Yates CJP, Berent A, Andrews V, Dormandy JA. Increase in leg blood flow by normovolaem haemodilution in intermittent claudication. Lancet 1979;ii: 166-8.

15 Anonymous. Haemoglobin and the ischaemic foot [Editorial]. Lancet 1979;ii:184-5.

16 Meemer K, Schmidt-Schonbein H, eds. International hemodilution. Basle: S Karger, 1975.

17 Grindon AJ, Tomasulo PS, Bergin JJ, Klein HG, Miller JD, Mintz PD. The hospital transfusion committe; guidelines for improving practice. FAMA 1985;253:540-3. 